\title{
The influence of post-consumer car mats waste on selected concrete parameters
}

\author{
Alina Pietrzak ${ }^{1, *}$, Matgorzata Ulewicz $^{1}$ \\ ${ }^{1}$ Czestochowa University of Technology, Faculty of Civil Engineering
}

\begin{abstract}
In recent years, a systematic increase of various types of wastes has been observed, including polymeric wastes that, to a large degree, are difficult to manage. The present paper deals with the problem of car mats wastes and the possibility of their application for producing concrete composites. The scope of the research involved designing and making concrete mixtures modified by waste rubber retrieved from rubber car mats. For the experiment the authors used: Portland cement CEM I 42,5R, sand, gravel aggregate of the $2-8$ and $8-16$ fractions, water, plasticizing and aerating admixture and car mats wastes fragmented into $0-2 \mathrm{~mm}$ and 2-8 $\mathrm{mm}$. The authors made 4 series of concrete samples modified by wastes, for which the following factors have been assigned: compression strength after 7 and 28 days of maturing, absorptivity, frost resistance F100 of freezing and thawing and bulk density. In two samples' composition (S1 and S2) the authors used 2-8 $\mathrm{mm}$ fraction rubber wastes as a substitute for $2-8 \mathrm{~mm}$ gravel in the amount of $5 \%$ and $7,5 \%$ of the cement bulk, making the density correction of 2-8 gravel. In contrast, in the remaining two samples S3 and S4 were modified by rubber wastes of the $0-8 \mathrm{~mm}$ fraction in the amount of $5 \%$ and $10 \%$, respectively, of the cement bulk, subtracting a certain amount of the aggravate mixture at the same time. The research conducted for the series of the designed concrete samples; unfortunately did not confirm the thesis that rubber wastes retried from rubber car mats could be reused as the aggravate substitute.
\end{abstract}

\section{Introduction}

The process of recycling of polymeric wastes, characterised by its diversity of chemical structure and composition (apart from polymers the materials contain extenders, reinforcing softeners, UV stabilizers, antioxidants, and colouring matters) embodies numerous technical and technological limitations $[1,2]$. Therefore, such heterogeneous polymeric wastes, like post-consumer car mats are, in fact, stored on waste landfills. In accordance with Directive 2008/98/WE the amount of wastes produced should be limited. Furthermore, effective ways of waste management should also be sought. Unfortunately, in practice the standard of polymers recycling is rather low - in Europe in 2014 the level of such waste management equalled only $29,7 \%$ [3].

${ }^{*}$ Corresponding author: apietrzak@bud.pcz.czest.pl 
Car mats are most often made of needle-felt velour (polypropylene or polyamide) finished with rubber pulp (for example polybutadiene, polyolefin) [4]. There are also car mats made of Poly(ethylene terephthalate), also known as PET and polyethylenepolypropylene copolymer [5]. In addition, the mats contain fire retardant, mineral fillers and colouring matters. Segregation of such wastes is ineffective, which in turn means that resource recycling is impossible and material recycling is greatly limited. Therefore, seeking new possibilities to use post-consumer car mats is an important subject matter in view of natural environment protection and the reduction of resources consumption.

Due to its resistance and possibility of effective shaping of modern architecture, concrete is the most commonly used construction material. Literature states that concrete and concrete composites production technology undertakes attempts to dispose of all sorts of polymeric wastes: PET wastes [6, 7], ABS wastes [8, 9], PUR wastes [10], car tyres wastes [11-14]. Research on reusing polymeric recyclates as the substrata taking part in the technology of production of mortar and concrete mixtures produces positive results in those wastes' management, which is an extremely crucial ecological factor. Therefore, the aim of the paper was to determine various possibilities to reuse polymeric wastes, retrieved from car mats, as a substitute for aggregate in concrete.

\section{Materials and research methods}

For research the following types of concrete were used: Portland cement CEM I 42,5R, sand, gravel aggregate of the 2-8 and 8-16 mm fractions, water, plasticizer MasterPozzolith STD and post-consumer car mats (Fig. 1a) fragmented into 2-8 $\mathrm{mm}$ (A) (Fig.1b) and into 0-2 mm (B) (Fig.1c). The chemical composition is given in Table 1.

a)

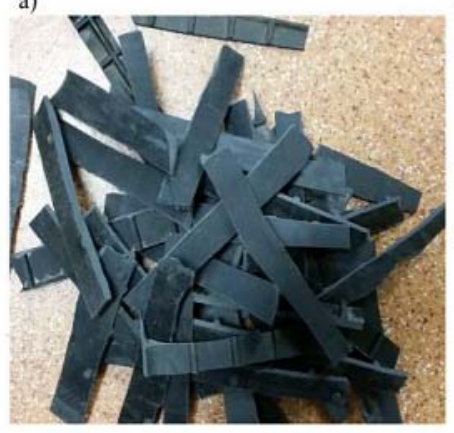

b)

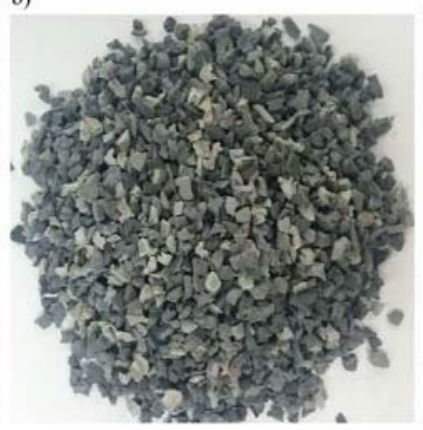

c)

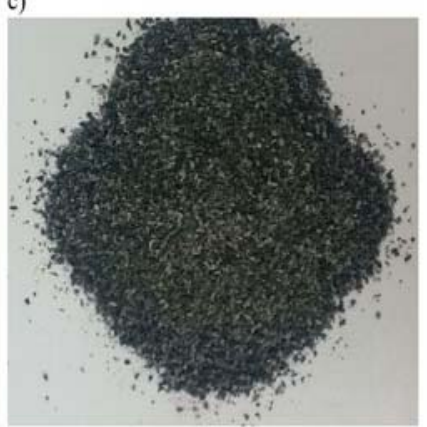

Fig. 1. Car mats (a) prefragmented; (b) fragmented to $2-8 \mathrm{~mm}$ fraction; (c) fragmented to $0-8 \mathrm{~mm}$ fraction. (Photo by the authors).

Table 1. Chemical composition of the wastes.

\begin{tabular}{|c|c|c|c|c|c|c|c|c|}
\hline \multicolumn{10}{|c|}{ Chemical composition [\% of bulk] } \\
\hline $\mathbf{C a O}$ & $\mathbf{S i O}_{\mathbf{2}}$ & $\mathbf{A l}_{\mathbf{2}} \mathbf{O 3}$ & $\mathbf{Z n}$ & $\mathbf{M g O}$ & $\mathbf{S}$ & $\mathbf{T i O}_{\mathbf{2}}$ & $\mathbf{P}_{\mathbf{2}} \mathbf{O}_{\mathbf{5}}$ & $\mathbf{F e}_{\mathbf{2}} \mathbf{O}_{\mathbf{3}}$ \\
\hline 46.96 & 12.93 & 2.97 & 2.55 & 2.21 & 0.98 & 0.89 & 0.72 & 0.35 \\
\hline $\mathbf{K}_{\mathbf{2}} \mathbf{O}$ & $\mathbf{C l}$ & $\mathbf{B a}$ & $\mathbf{W}$ & $\mathbf{A s}$ & $\mathbf{P b}$ & $\mathbf{S r}$ & $\mathbf{P t}$ & $\mathbf{Z r}$ \\
\hline 0.19 & 0.19 & 0.11 & 0.066 & 0.065 & 0.052 & 0.018 & 0.017 & 0.009 \\
\hline
\end{tabular}


5 series of samples were made. Control concrete sample with the $\mathrm{w} / \mathrm{c}=0,55$ ratio with the addition of plasticizer in the amount of $0,3 \%$ of the cement mass - (SK) series. In the subsequent attempts the control concrete was modified as follows:

- series 1 - using rubber wastes (A) in the amount of 5\% of the cement bulk, making the density correction of the gravel aggregate.

- series 2 - using rubber wastes (A) in the amount of 7,5\% of the cement bulk, making the density correction of the gravel aggregate.

- series 3 - using rubber wastes $(\mathrm{A}+\mathrm{B})$ in the amount of $5 \%$ of the cement bulk, making the density correction of the aggregate (gravel aggregate and sand).

- series 4 - using rubber wastes $(\mathrm{A}+\mathrm{B})$ in the amount of $10 \%$ of the cement bulk, making the density correction of the aggregate (gravel aggregate and sand).

The composition of particular concrete mixtures is given in Table 2.

Table 2. Composition of the concrete mixtures with addition of $\mathrm{A}$ and $\mathrm{B}$ waste samples.

\begin{tabular}{|c|c|c|c|c|c|c|}
\hline \multirow{2}{*}{$\begin{array}{c}\text { Concrete } \\
\text { series }\end{array}$} & \multicolumn{6}{|c|}{ Substrata $\left(\mathbf{k g} / \mathbf{m}^{\mathbf{3}}\right)$} \\
\cline { 2 - 7 } & Cement & Water & Aggragate & Plasticizer & \multicolumn{2}{|c|}{ Additive } \\
\cline { 2 - 7 } & & & & & A & A+B \\
\hline SK & 313.3 & 173.9 & 1918.2 & 0.94 & - & - \\
\hline S1 & 313.3 & 173.9 & 1884.7 & 0.94 & 15.67 & - \\
\hline S2 & 313.3 & 173.9 & 1867.9 & 0.94 & 23.50 & - \\
\hline S3 & 313.3 & 173.9 & 1884.7 & 0.94 & - & 15.67 \\
\hline S4 & 313.3 & 173.9 & 1851.2 & 0.94 & - & 31.33 \\
\hline
\end{tabular}

Samples for measuring compressive strength were made in forms according to requirements of the Norm PN-EN 12390-1. For all series of concrete samples there were twelve $15 \times 15 \times 15 \mathrm{~cm}$ cubic samples and twelve 10x10x10 cm samples formed according to norm PN-EN 12390-2.

\section{Results of the research}

The experiment of durability of compressive strength was conducted after 7 and 28 days of sample maturing under laboratory conditions according to norm PN-EN 206:2014 Concrete - "Specification, performance, production and conformity". The experiment was carried out by mean of Toni Technik type 2030 testing machine according to the Norm. The results are presented in Table 3. Figure 1 shows the reduction of average compression strength within particular modified concrete series in relation to the control concrete series.

With the experimentally assumed water/cement ratio the concrete mixture was designed in the way to gain appropriate consistency and workability. For the control concrete series the S3 consistency was assumed (slump within 100-150 mm). The average compressive strength of the control concrete series (SK), measures after 7 days was $\mathrm{f}_{\mathrm{cm}}=36.2 \mathrm{MPa}$. Adding, both 2-8 $\mathrm{mm}$ fraction wastes as well as $0-8 \mathrm{~mm}$ fraction wastes, respectively as the substitute of gravel and as a substitute of aggregate mixtures caused the decrease in average compressive strength. After 7 days of maturing, the biggest decrease (23.4\%) of compressive strength in relation to the control concrete series was observed in S2 series. The smallest decrease (11.1\%) in compressive strength was examined in S1 series. The average compressive strength of the control concrete series (SK), measures after 28 days $\mathrm{f}_{\mathrm{cm}}=46.6 \mathrm{MPa}$. In all series (S1-S4) a decrease in average compressive strength in relation to the control concrete series was noticed. The smallest, $8 \%$ decrease in compressive strength was observed in S4 series. 
Table 3. Results of the compressive strength, absorbability and density of concrete samples in particular series.

\begin{tabular}{|c|c|c|c|c|}
\hline \multirow{2}{*}{$\begin{array}{c}\text { Concrete } \\
\text { series }\end{array}$} & \multicolumn{2}{|c|}{$\begin{array}{c}\text { Average compressive strength } f_{c m} \\
\text { (MPa) }\end{array}$} & \multirow{2}{*}{$\begin{array}{c}\text { Absorbability } \\
n_{w} \\
\text { (\% of bulk) }\end{array}$} & \multirow{2}{*}{$\begin{array}{c}\text { Volumetric } \\
\text { density } \\
\rho\left(\mathbf{k g} / \mathbf{m}^{3}\right)\end{array}$} \\
\hline & $\begin{array}{l}\text { After } 7 \text { days of } \\
\text { maturing }\end{array}$ & $\begin{array}{l}\text { After } 28 \text { days } \\
\text { of maturing }\end{array}$ & & \\
\hline SK & 36.2 & 46.6 & 5.9 & 2227 \\
\hline S1 & 32.2 & 42.3 & 5.8 & 2342 \\
\hline $\mathrm{S} 2$ & 27.8 & 36.6 & 6.1 & 2329 \\
\hline S3 & 29.2 & 38.9 & 6.0 & 2337 \\
\hline S4 & 28.2 & 42.9 & 6.0 & 2337 \\
\hline
\end{tabular}

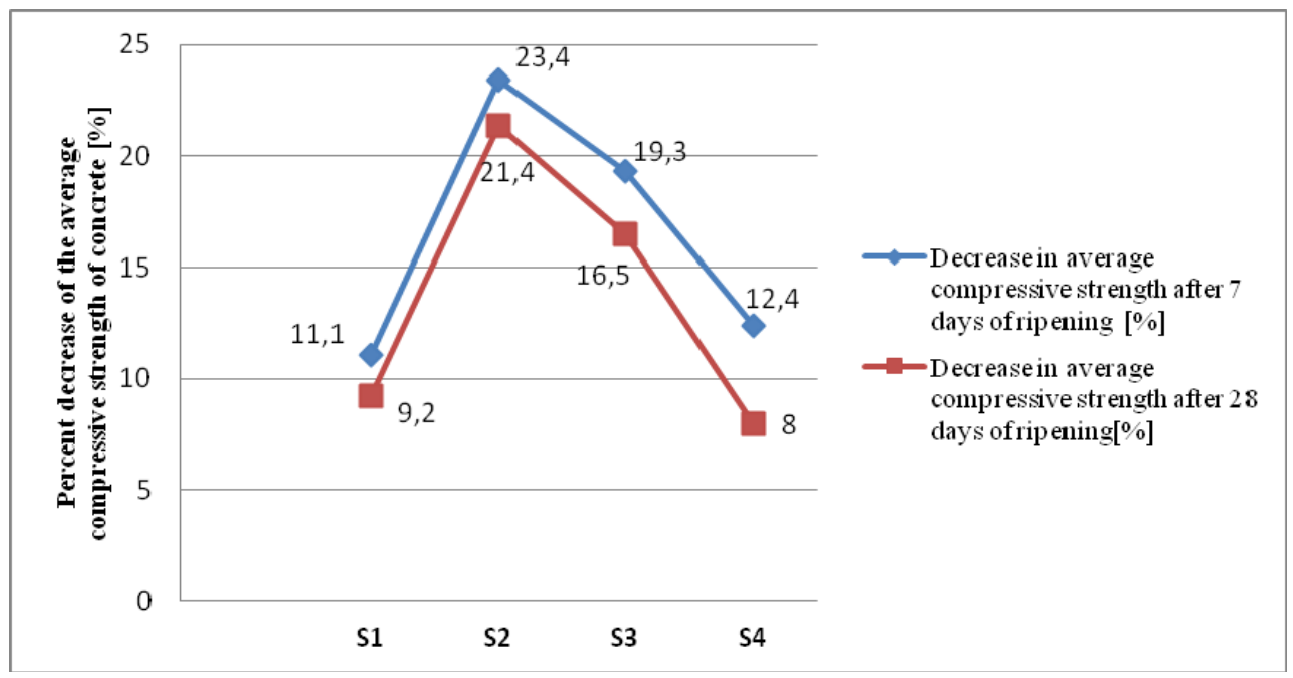

Fig. 2. Percent decrease of the average compressive strength of concrete in particular series in relation to the control series (SK).

On the basis of the methodology included in Norm PN-88/B-06250 Plain Concrete, an experiment of absorbability of particular series was conducted. The results are presented in Table 3. According to the above-mentioned Norm, the absorbability of concrete exposed to environmental influences should not be bigger than 5\%. However, for concrete protected from direct weather conditions should not be bigger than $9 \%$. Both the control concrete and the modified by means of car mats concrete reached the absorbability within $5.8-6.1 \%$.

Using direct method (PN-88/B-06250) the authors conducted a finding out of concrete frost-resistance for a F100 resistance class. The results are given in Table 4. The analytical determination is taken as positive if after carrying out of $n$ cycles of freezing and thawing, required by certain frost resistance class: the average decrease of compressive strength does not exceed $20 \%$, the average loss in mass does not exceed $5 \%$ and none of the examined samples breaks or scratches.

The decrease of resistance for alternate freezing and thawing of the control series equalled $16.5 \%$. As presented in Table 4, the S3 and S4 concrete series modified by means of waste $(\mathrm{A}+\mathrm{B})$ showed much smaller decrease of resistance for alternate freezing and thawing, which equalled from 4.7 to $5.8 \%$ in relation to the control series. Smaller decrease of resistance after the finding out of concrete frost-resistance in relation to the SK series was also observed in S1 and S2 series and it equalled 16.1 and 10.4 respectively. The loss of mass for all concrete series was in the range of between $0.10-0.21 \%$. 
Table 4. Results of the finding out of concrete frost-resistance for all concrete series.

\begin{tabular}{|c|c|c|}
\hline \multirow{2}{*}{$\begin{array}{c}\text { Concrete } \\
\text { series }\end{array}$} & \multicolumn{2}{|c|}{ Frost-resistance } \\
\cline { 2 - 3 } & Average mass loss $\boldsymbol{\Delta G} \mathbf{( \% )}$ & $\begin{array}{c}\text { Average decrease } \\
\text { of compressive strength } \boldsymbol{\Delta R}(\mathbf{\%})\end{array}$ \\
\hline SK & 0.12 & 16.5 \\
\hline S1 & 0.10 & 16.1 \\
\hline S2 & 0.21 & 10.4 \\
\hline S3 & 0.12 & 4.7 \\
\hline S4 & 0.16 & 5.8 \\
\hline
\end{tabular}

\section{Conclusions}

The research conducted for the concrete designed did not confirm the possibility to reuse the car mats wastes as a substitute of aggregate in concrete. The examined waste modified concrete series obtained smaller resistance for drainage. Furthermore, the remaining parameters were on the comparable level corresponding to the control series. Waste modified series showed better frost-resistance, due to a smaller decrease of compressive resistance.

\section{References}

1. M. Ulewicz, J. Siwak, Procesy odzysku i recyklingu wybranych materiałów, Wydawnictwo PCz, Częstochowa (2013)

2. Zielona Księga w sprawie europejskiej strategii dotyczącej odpadów z tworzyw sztucznych w środowisku, Bruksela, COM,123 (2013)

3. www.teraz-srodowisko.pl

4. www.autodywaniki.pl

5. R. Komornicki, R. Jeziórska, A. Abramowicz, Z. Wielgosz, Recykling odpadów wykładzin samochodowych, Przetwórstwo Tworzyw, 3, 208-212 (2013)

6. Y.-W. Choi, D.-J. Moon, J.-S. Chung, S.-K. Cho, Effects of waste PET bottles aggregate on the properties of concrete, Cement and Concrete Research, 35, 776-781 (2005)

7. D. A. Silva Betioli, A.M., Gleize P.J.P., H.R. Roman, L.A., Gómez, J.L.D. Ribeiro, Degradation of recycled PET fibers in Portland cement-based materials, Cement and Concrete Research, 35, 1741-1746 (2005)

8. C. Albano, N. Camacho , M. Hernandez, A. Matheus , A. Gutierrez, Influence of content and particle size of waste pet bottles on concrete behavior at different $\mathrm{w} / \mathrm{c}$ ratios, Waste Management, 2707-2716 (2009)

9. J. Jura, M. Ulewicz, Use of the waste materials in cement mortars, JCEEA, 33, 247-254 (2016)

10. V. N. Antsiferov , T.S. Golodnova, S.E. Porozova , G.R. Sagirova , Use of waste materials from the production of synthetic rubber for preparing aluminosilicate ceramics, Refractories and Industrial Ceramics, 43, 299-302 (2002)

11. A. Palos, N.A. D’Souza, C.T. Snively, R.F.Reidy, Modification of cement mortar with recycled ABS, Cement and Concrete Research, 31, 1003-1007 ( 2001)

12. P. Mounanga, W. Gbongbon, P. Poullain, P. Turcry, Proportioning and characterization of light weight concrete mixtures made with rigid polyurethane foam wastes, Cement and Concrete Composites, 30, 806-814 (2008) 
13. N. A. Ali., A.D. Amos, M. Roberts, Use of Ground rubber tires in portland cement concrete. In: Proceedings International Conference on Concrete 2000, University of Dundee, UK, 379-390 (2000)

14. N.N. Eldin, A.B. Senouci, Rubber tire particles as concrete aggregate. Journal of Materials in Civil Engineering, 5, 478-496 (1993) 